\title{
Use of alcohol and other drugs among male university students and its meanings*
}

\section{Uso de álcool e outras drogas entre universitários do sexo masculino e seus significados Uso de alcohol y otras drogas entre universitarios del sexo masculino y sus significados}

Eliza Maria Rezende Dázioํㅜ, Márcia Maria Fontão Zago² ${ }^{2}$ Silvana Maria Coelho Leite Fava ${ }^{1}$

How to cite this article:

Dázio EMR, Zago MMF, Fava SMCL. Use of alcohol and other drugs among male university students and its meanings. Rev Esc Enferm USP. 2016;50(5):785-791. DOI: http://dx.doi.org/10.1590/S0080-623420160000600011

*Extracted from the project “Atenção à saúde do estudante universitário: uma proposta interdisciplinar de uma instituição pública do sul do estado de Minas Gerais," Universidade Federal de Alfenas, 2012.

${ }^{1}$ Universidade Federal de Alfenas, Escola de Enfermagem, Alfenas, Minas Gerais, Brazil.

${ }^{2}$ Universidade de São Paulo, Escola de Enfermagem de Ribeirão Preto, Ribeirão Preto, São Paulo, Brazil.

\begin{abstract}
Objective: To understand the meanings that male university students assign to the condition of users of alcohol and other drugs. Method: An exploratory study using a qualitative approach, with inductive analysis of the content of semi-structured interviews applied to 20 male university students from a public university in the southeast region of Brazil, grounded on the theoretical-methodological referential of interpretive anthropology and ethnographic method. Results: Data were construed using content inductive analysis for two topics: use of alcohol and/or drugs as an outlet; and use of alcohol and/or other drugs: an alternative for belonging and identity. Conclusion: Male university students share the rules of their sociocultural environment that values the use of alcohol and/or other drugs as a way of dealing with the demands and stress ensuing from the everyday university life, and to build identity and belong to this social context, reinforcing the influence of culture.
\end{abstract}

\section{DESCRIPTORS}

Students; Drug Users; Alcoholism; Masculinity; Public Health Nursing. 


\section{INTRODUCTION}

In Brazil and worldwide the use and abuse of alcohol and/or other legal and illegal drugs is gradually increasing among people of all social classes, notably among youth. It is a public health issue that deserves more attention today because of its cultural, ethical-legal, political, economic, and technological determinants and constraints that have impacts on individuals, families, and society. In this way, it demands attention not only from parents and tutors of youth, but also from society, educators, health professionals, and the scientific community ${ }^{(1-4)}$.

Youth pursue personal growth and a profession in the university environment; however, this social environment can facilitate starting and continuing uncontrolled use of alcohol and other legal and illegal drugs ${ }^{(5-6)}$.

The excessive use of alcohol and other psychoactive substances can reduce university students' life expectancy because it exposes them to traffic accidents; episodes of interpersonal violence; unprotected sexual relations and HIV transmission; sleep disorders; changes in eating habits; reduction of perception; stress; and academic deficits ${ }^{(5-7)}$. Another serious consequence is the addiction that can lead to mental or physical deficits in users ${ }^{(1)}$.

In this context, the university is responsible for caring about the technical-scientific and ethical nurturing of academics and citizens, notably their health. Consequently, efforts should be made to promote preventive measures to fight the use of legal and illegal drugs; measures of therapy; and reinsertion into the society and university life. This demands analyzing and understanding the factors that influence students to consume alcohol and/or other drugs, to let them develop their intellectual capabilities and cope with the adversities resulting from academic demands and distance from family members ${ }^{(5,8)}$.

Some studies acknowledge that this stage of life is complex, and support services to students in higher education institutions have tried to implement policies for student care, which are still in the early stages. Personal experiences and difficulties inherent to this period of life have not been effectively appraised with regard to undergraduate course contents.

It is worth observing that involvement with alcohol and/or other drugs affects both men and women, but women are affected to a lesser extent ${ }^{(4,5,9)}$. We believe that some behaviors are socially learned, and involvement with the use of alcohol and other drugs may be related to the sociocultural constructs of gender and masculinity, considering that from the time they are born men are induced to have male attitudes ${ }^{(10)}$. This statement is in line with the theoretical reference of this study, which advocates that behaviors are determined by the sociocultural environment, and that individuals act based on the meanings they assign to alcohol and other drugs ${ }^{(11)}$.

In this light, "masculinity is not a fixed entity incarnated in the individuals' body or traits of personality. Masculinities are configurations of practices performed in social action and, this way, can vary according to gender relations in a given social setting. Therefore, hegemonic masculinities can be built in a way that does not genuinely correspond to the life of any real man"(12).

The use of alcohol and other drugs among university students seems to be a usual practice, as evidenced by party invitations on folders, banners, and flyers, usually on the universities' access gates, inviting students to events of this nature promoted in the city. This is a concerning reality that raises interest to deepen our knowledge from the university students' viewpoint since we, as professors and nurses, are committed to the issue of use of these psychoactive substances among students from a public university in the southeast region of Brazil. We have given priority to male university students in line with the National Policy of Comprehensive Care to Men's Health (PNAISH) ${ }^{(13)}$ and the National Policy on Drugs ${ }^{(14)}$, the epidemiological data of which urge a specific approach to recommend measures of prevention, promotion, therapy, and rehabilitation of this population share $\mathrm{s}^{(5)}$.

This study aimed to understand the meanings that male university students assign to the condition of users of alcohol and other drugs.

\section{METHOD}

To respond to our concerns, we have used the interpretive anthropology ${ }^{(11)}$ referential that focuses on culture and advocates for the ethnographic method to pursue dense description. Based on minor facts densely intertwined, we can acquire the analysis and construing, expanding the understanding of the role played by culture in the construction of collective life. In this light, the experience of using alcohol and other drugs is a way to organize the male university student's life, build meaning, or define identity, considering that in the academic environment the use and consumption of these psychoactive substances permeates meetings and celebrations that are social and collective spaces of university life, where students are eager to belong. The signifier "drug" may bear different meanings ${ }^{(11)}$, depending on the group that interprets it.

In this light, the method selected is suitable because it allows learning about the experience from the one who experiences it. The search for dense description is a challenge not only because of the method, but for the complexity of this matter and approach of male university students, a quite different context than that of the female researchers.

Fieldwork was performed from November 2014 to July 2015 at the university facilities and respondents' homes. The field of research was accessed by inserting the main researcher into the groups of undergraduate students in the university spaces, supported by three research assistants, which enabled the participation of students from different courses and stages.

During class breaks the researchers introduced themselves to students, explained the study objective, and invited the students to participate in the survey. In principle, some university students were somewhat apprehensive, but some students previously contacted helped in clarifying doubts, mainly regarding the approach to drugs in the study, which 
was not limited to illegal drugs, but included all sorts of drugs such as alcohol, tobacco, anxiolytics, and amphetamines. Researchers also explained that if students were interested in participating, the researchers would be available in the university corridors and spaces where students socialized. Then the interested students sought them out.

Students from early terms did not express interest, although they were invited to participate. However, students in the later terms voluntarily sought out the researchers to participate in the study. The researchers again explained the survey objective, data collection techniques, and booked meetings at the university or at home depending on the students' availability.

Before collecting data at the university or home, the researcher asked the students to sign two counterparts of the Free and Informed Consent Term (FICT) respecting the ethical aspects set forth by the National Health Council Resolution \#466 of December 12, 2012 ${ }^{(15)}$. The researchers delivered one copy to the participants and file the other copy. To ensure anonymity, participants were assigned fictitious names selected by themselves. This survey was approved by the Committee of Ethics in Research of the Federal University of Alfenas, Report \#822626.

The instrument had two parts; one comprised sociodemographic and academic data such term/course, and the other asked the following guiding question: Tell us, in your view, what it means to be a university student and use alcohol and/or other drugs.

The interview was recorded using a digital recorder, with the participants' permission. On average, each participant was interviewed two to three times, and each interview lasted 40 minutes. Observation of the participants and the field journal showed aspects of the context where data were being collected, as well as perceptions gathered by the main researcher. These aspects were recorded at different moments of the meetings with academics in different settings, as they were crucial to contextualize and describe the facts and behaviors, and also to clarify the issues approached in the interview ${ }^{(11)}$.

Interviews were transcribed in full immediately after being made, numbered in ascending sequence, and electronically filed using Word for Windows. Data on the observation of participant and field journal were integrated to these texts. Data were read and reread exhaustively, and the inductive content analysis led to the selection of the structure of signifiers, and to the setting of codes to determine its social ground and importance according to the theoretical-methodological referential adopted. This was in consideration of the fact that the object of ethnography is made of structures of signifiers and ethnographers should try to understand such structures, presented as an overlapping of inferences and implications ${ }^{(11)}$.

\section{RESULTS}

Twenty male undergraduate students participated, of whom nine were from the area of Health Sciences, seven from Human Sciences and Languages/Literature area, and four from Exact Sciences. Ages ranged from 20 to 32 years, with a prevalence of individuals aged 25 years old. All participants were single, most of them self-declared to be white, Catholic, and with a family income of four minimum wages. Fourteen lived in fraternities, four lived with their parents, and two shared a home with a colleague. Regarding personal income, one participant worked; seven were fellows-two of Scientific Initiation and one of the Tutorial Education Program (PET, in Portuguese). Only one lived on a scholarship of $\mathrm{R} \$ 400.00$ with no support from the family. We considered that the field work with 20 participants and data analysis were enough to reach the objective of this study.

Results were categorized into two topics: Use of alcohol and/or drugs as an outlet; and use of alcohol and/or other drugs: an alternative to belonging and identity.

\section{USE OF ALCOHOL AND/OR OTHER DRUGS AS AN OUTLET}

Below are the statements by university students about the use of alcohol and/or other drugs as a way of attenuating the activities imposed by academic life.

(...) ob! Alcohol, I think it is an outlet to minimize problems and responsibilities that college imposes on us. And the cigarette to relieve stress, anxiety; this kind of thing. But I have used some times... like marijuana... if I say it was once, I'll be lying. (E1 - Adriano)

Pedro considered it (...) a kind of outlet from reality and an option of recreational use to reduce everyday stress that we suffer. What comes to my mind: change of perception about reality and, as such, an outlet. (E1 - Pedro)

Cesar highlighted: (...) I smoke more marijuana by the end of the term, before tests or after taking the test, marijuana also helps me to think, write. I feel really relaxed, calm. (E1 - Cesar)

Mauricio and Julio said they use drugs to relieve pressures: (...) alcohol, in one single word, I believe it is a refuge. Because it relaxes people and people are eager for the end of the day to enjoy the happy hour, enjoy this feeling of pleasure because their everyday is in anxiety, stress, and they consider alcohol and other drugs as the only way for relaxing. (E1 - Mauricio)

(...) so, at least as I see it, it is a sort of escapism. Sometimes we drink a little to escape from problems, maybe as entertainment, to escape from the social pressure that we somehow suffer, I think it is because of it. It's a way of having fun. I guess it is, in this sense, lose consciousness a little. I use to have fun. It is a form of escapism, a way to get away from the so busy reality that we live, this kind of thing. (E1- Julio)

\section{USE OF ALCOHOL AND/OR OTHER DRUGS: AN ALTERNATIVE TO BELONGING AND IDENTITY}

Rodrigo's statement showed the building of relationships permeated by the use of these psychoactive substances. He does drugs: (...) at parties, with friends, in the fraternity, really to socialize. I have never been pressed, but access was easy; there's always someone offering something, mainly at parties (E2 - Rodrigo).

The use of drugs can favor relationships including those with the opposite sex: (...) in a pub, or I go to a party and 
end up by having some drinks. It helps making out, we are more relaxed, get closer. People are shier, more enclosed in their own world. We need a trigger to get together and talk to the other person. (E2 - Levi). And Pedro added: (...) alcohol loosens up and surely helps approaching the opposite sex and minimizing the lack of confidence. Marijuana is a more introspective drug, makes us feel more relaxed, more thoughtful, you see? Sensibility is different, physical contact is more pleasant. [Silence] I guess men use it mainly because of the existing social pressure. You have to use alcohol to be accepted in social circles. (E2 - Pedro)

Freedom is a characteristic trait in the statements about men's meeting. Julio said: (...) here, we have the people that live here and what we call the added ones, that don't live here but are always here. We hang out, have drinks, smoke together, play soccer... we have a large circle of friends. That's what we say about freedom, a group of freedom. You put together a lot of people seeking freedom; let's do something different. Everyone here smokes marijuana and I smoke cigarettes, sometimes to interact, this thing of building a sort of community spirit at different levels. Not only drugs, it can also be a fad, our society; Western society is this way. (E2 - Julio)

Alexandre's statement shows the influence of culture on the experience of using alcohol and/or other drugs: (...) I guess also influenced by, let's say, living in a place where many smoke; it may somehow stimulate. I mean, facilitates to you, makes it easy; then you start seeing that as a routine. And, let's say, what happened was... breaks the taboo, demystifies the thing, you know? You start handling that. (E3 - Alexandre)

Participants consider enjoying university life important and the sensations that drugs bring, but also emphasized that they try to develop self-control strategies to prevent compulsive use of drugs.

(...) think that to many people university means freedom. We are free and must enjoy it. It's now or never! But I believe, I think it's fair to suck all the marrow of life, but you must be careful not to choke on the bone. There are limits. Limit, I believe it. Alcohol has not caused much damage to me because I somehow can balance it. If I have something to study tomorrow I don't drink too much today. At least I have never had problems but, if I have something to study and drink too much tonight, tomorrow I'll have difficulties in thinking clearly, about everything. (E2 - Julio)

And Alexandre adds: (...) my mother has a saying, and my father also says it, that everything in excess damages; even an excess of happiness causes damages. In the actual academic life I can't say I have failed a test because I smoked marijuana; it never happened to me. I guess I'm a little bit responsible. (E2 - Alexandre)

\section{DISCUSSION}

\section{USE OF ALCOHOL AND/OR OTHER DRUGS AS AN OUTLET}

In the common sense, entering higher education means an opportunity to achieve a profession. However, many factors can cause university students to make use of controlled substances, such as the interruption of previous practices and routines, distance from their families ${ }^{(9)}$, the need fit into an unknown environment, establishment of new friendship links, new forms of leisure, independence, new challenges posed by academic life, concerns about future insertion into the labor market, and the greater possibility of access to legal and illegal drugs ${ }^{(1,6,16)}$.

The poly-drug use standards and their gender, as well as the social and legal implications among university studies were due to the stress $^{(4)}$ generated by university tasks and in order to obtain physical and mental relaxation, including in the university. In addition, the preferred days to use these substances were Fridays and Saturdays, showing that use is not only aimed to handle everyday academic pressures, but also on social occasions ${ }^{(4-5)}$. This study found similar results.

We would like to reaffirm that, to common sense, alcohol, tobacco, and other drugs alleviate the pressures and sufferings of life. We believe this practice is associated with sociocultural constructs ${ }^{(11)}$, because the use of psychoactive substances is a millenary and universal practice recorded throughout human history, in different cultures and contexts for different purposes, including as medicine or poison, in divine or demonized forms, and for pleasure ${ }^{(17)}$.

On the other hand, one should consider that stress ${ }^{(4)}$ is related to the new demands of university life that imply coping with new challenges, building identity as a university student, and meeting the expectations of this new space for socialization and professional training. To fit into this context, university students change their behaviors under the influence of the social rules of the social group in which they select to socialize ${ }^{(11)}$. During their academic lives they learn the importance of acquiring the knowledge and skills that will be required to succeed in their professional and male adult lives after graduation, and of increasing competitiveness. To those for whom coping with these challenges is harder, drugs may be an outlet.

In Brazil, the use of these substances is permeated by a cultural legacy both from the native population and from our colonizers and immigrants. Understanding this history is crucial to understanding the origin of moralist stigmas and erroneous concepts that end by marginalizing people that make use of these substances ${ }^{(18)}$. Therefore, the experience of using psychoactive substances is cultural and, thus, determines the behavior towards deciding for and doing drugs ${ }^{(11,17,19)}$.

We learn that when students enter the university they gradually reconstruct their web of meanings, because culture is dynamic ${ }^{(11)}$ and arises from interaction with new social groups. Influenced by this interaction, they find in these substances a means to minimize sufferings and find moments of pleasure ${ }^{(19)}$.

In our contemporary individualist society we live the absolutizing of the present; that is, life is now and not lat$\mathrm{er}^{(20)}$. Each one must be happy and achieve a fulfilled life in the field of consumption ${ }^{(20)}$. In this sense, each society presents different cultural forms for what a fulfilled life would mean and, if this project fails, the person reports depression, sleep disorders, distress, loneliness, emptiness, and drug addiction. 
USE OF ALCOHOL AND/OR OTHER DRUGS: AN ALTERNATIVE TO BELONGING AND IDENTITY

Considering that the university environment is favorable to trying alcohol and/or other drugs because of easy access $^{(9)}$ and because use among students is considered to be natural, students start or continue doing it as a way of belonging and interacting, a ritual of transition to adult life, of courage, freedom, sexual pleasure ${ }^{(1)}$, and reaffirmation of masculinity.

Studies showed that university students started and continued using alcohol and/or other drugs as a consequence of the need to participate in social activities and the availability of these substances in their relational circles ${ }^{(6,9)}$.

A study about sexuality and drug addiction reaffirmed that adolescents and young adults seek psychoactive substances to increase their libido and pleasure and facilitate the closeness of individuals ${ }^{(21)}$. Our study found similar results, considering that university students justified using alcohol and/or other drugs as a way to loosen up with the opposite sex and as a way of reaffirming their masculinity.

In low amounts, alcohol can maximize sexual desire. In high amounts, in contrast, it can jeopardize erection and cause premature ejaculation ${ }^{(21)}$.

Regarding marijuana, few studies approach the links between it and sexuality; however, considering the controversial results, this topic deserves deeper investigation. A study showed that men that used drugs and were in therapy reported difficulties in reaching orgasm and erection. On the other hand, according to some reports, marijuana can promote sexual meetings, increase libido, and extend orgasm. Sexual pleasure induced by this drug can contribute to increasing the number of sexual partners and predispose the user to sexually transmitted diseases ${ }^{(20)}$.

The sense of freedom intensified by distancing from family and the belief that university life is a phase of freedom and autonomy favors exploring and satisfying curiosity, which leads these students to try psychoactive substances to feel different sensations ${ }^{(1)}$. As they said: I'll drink until I leave my body.

A refined view of the other's experience is crucial to listening beyond what has been said ${ }^{(11)}$. To the common sense, life in the university is marked by freedom, including parties, barbecues, and the use of psychoactive substances. On the other hand, those who do not share the group's behaviors can feel marginalized and be excluded, showing weakness and losing domain in public spaces, in opposition to the culturally built ideals of masculinity ${ }^{(12)}$.

Other reasons to use psychoactive substances include amusement and pleasure, typical to this age group ${ }^{(1)}$.

Our attention was called to the fact that these students considered it important to enjoy the university life and the sensations that drugs bring, also emphasizing that they try to develop self-control strategies to prevent compulsive use of drugs.

During talks, the participants said they had already made lots of messes and drunk a lot, but were now quieter (Field Journal 04/23/2015). Many affirmed that concluding their university degree reflects changes and, as they said, now they had to "focus," take on responsibilities such as a job, marriage, and children, and this could contribute to reducing or ceasing the use of psychoactive substances ${ }^{(8,21)}$.

The social constructions of gender ${ }^{(22)}$ can contribute to this new view of the world. Being a man is never limited to sexual traits, but refers to a set of moral attributes of behaviors that are socially sanctioned, negotiated, and recalled. Regarding the male gender, it is worth emphasizing that it is not about a stereotyped denomination, because gender does not define the person. Being male involves a system of social interactions wherein the individual is inserted and that he uses to build his idea of masculinity. Therefore, hegemonic masculinity ${ }^{(22)}$ is defined as a patriarchal legitimacy that ensures a dominant position to university men, a power culturally established, that is, collectively accepted. Men soon learn that they must control many things, including stress, responsibilities, distancing from family, and socialization during university life through the use of drugs, in order to belong to their social group, as an expression of male identity ${ }^{(22)}$. We agree that men live in a society that controls their behaviors, which are socially judged as proper or not to their expression of gender and, many times, end up by reproducing these practices incorporating hegemonic masculinity. This behavior is passed from generation to generation ${ }^{(12,22)}$.

We learned that as these webs are woven drugs, as signifiers, take on different meanings in the life of each university student because each one starts having ${ }^{(11)}$ a new look at being in the university world and on their personal identity, with decisions about their future life as men and professionals.

We restate the need to review the planning and goals to be achieved by universities to comprise the actual needs of these people, implying a willingness to prevent drug use, reduce use of alcohol and/or other drugs, a commitment to care and referral for therapy and, above all, respect for the autonomy of students, free of social exclusion.

Despite the increasing number of studies about the use of alcohol and/or other drugs among university students, there is a need to gather researchers' efforts to closely see this experience, including through studies in the sociocultural light, giving voice and regarding users. This is also a way of providing inputs that can contribute even more to the planning and implementation of actions in line with university students' uniqueness that upholds their culture ${ }^{(11)}$. Bringing knowledge together is crucial because the dimension of use and abuse of these substances is not restricted to the arena of social detachment and discrimination, which does nothing but contribute to increase conditions of vulnerability. A refined view allowed learning that they cannot be labeled as drug addicts or "potheads", and even less be excluded from university society.

\section{CONCLUSION}

Alcohol was the most popular drug, followed by tobacco and marijuana. It can be perceived that masculinity can influence students towards starting to use these substances, 
referred to as an outlet from reality to minimize sufferings, and for belonging and identity, in response to the study objective.

Meetings with male undergraduate students enabled closer and inner views about the context investigated, and we learned that they share rules of their sociocultural environment that appraise the use of alcohol and/or other drugs, reinforcing the influence of culture on this experience.

As female researchers and professors, we found the development of studies on this topic with male undergraduate students a challenge. This aspect demanded extra care in the analysis process to avoid influencing the readings. Another limitation of the study was that most of the participants were in the final terms of undergraduate courses, with brief participation of students from early course stages, which has not been deepened.

The results of this study evidenced the importance of more efficient and feasible strategies respecting university students' autonomy. We recommend the establishment of socialization rooms to welcome these university students, and professional support to discuss and exchange experiences between students, incorporating the specific demands of men, with institutional participation and the participation of partner institutions.

\section{RESUMO}

Objetivo: Compreender os significados atribuídos pelos universitários do sexo masculino à condição de usuários de álcool e outras drogas. Método: Estudo exploratório de abordagem qualitativa, com análise de conteúdo indutiva de entrevistas semiestruturadas de 20 universitários do sexo masculino, matriculados em uma universidade pública da região sudeste do Brasil, fundamentado no referencial teórico-metodológico da Antropologia Interpretativa e do método etnográfico. Resultados: Os dados foram interpretados com a análise de conteúdo indutiva em dois temas: $\mathrm{O}$ uso do álcool e/ou drogas como válvula de escape; $\mathrm{O}$ uso do álcool e/ou outras drogas: alternativa para o pertencimento e para a identidade. Conclusão: Os universitários do sexo masculino compartilham normas de seu meio sociocultural, que valorizam o uso de álcool e/ou outras drogas, como uma forma de lidar com as exigências e o estresse da vida universitária, criar uma identidade e ter pertencimento neste contexto social, reforçando a influência da cultura.

\section{DESCRITORES}

Estudantes; Usuários de Drogas; Alcoolismo; Masculinidade; Enfermagem em Saúde Pública.

\section{RESUMEN}

Objetivo: Comprender los significados atribuidos por los universitarios del sexo masculino a la condición de adictos al alcohol y otras drogas. Método: Estudio exploratorio de abordaje cualitativo, con análisis de contenido inductivo de entrevistas semiestructuradas de 20 universitarios del sexo masculino, matriculados en una universidad pública de la región sureste de Brasil, fundado en el marco de referencia teórico-metodológico de la Antropología Interpretativa y del método etnográfico. Resultados: Los datos fueron interpretados con el análisis de contenido inductivo en dos temas: El uso del alcohol y/o drogas como válvula de escape; El uso del alcohol y/u otras drogas: alternativa para la pertenencia y la identidad. Conclusión: Los universitarios del sexo masculino comparten normas de su medio sociocultural, que valorizan el uso de alcohol y/u otras drogas, como una manera de manejar las exigencias y el estrés de la vida universitaria, crear una identidad y tener pertenencia en este contexto social, reforzando la influencia de la cultura.

\section{DESCRIPTORES}

Estudiantes; Consumidores de Drogas; Alcoholismo; Masculinidad; Enfermería en Salud Pública.

\section{REFERENCES}

1. Eckschmidt F, Andrade AG, Oliveira LG. Comparação do uso de drogas entre universitários brasileiros, norte-americanos e jovens da população geral brasileira. J Bras Psiquiatr [Internet]. 2013 [citado 2015 nov. 28];62(3):199-207. Disponível em: http://www.scielo.br/ pdf/jbpsiq/v62n3/04.pdf

2. United Nations Office on Drugs and Crime. World Drug Report, 2014 [Internet]. Viena: UNODC; 2014 [cited 2015 Oct 25 ]. Available from: https://www.unodc.org/documents/data-and-analysis/WDR2014/World_Drug_Report_2014_web.pdf

3. Wright MGM, Cumsille F, Padilha MI, Ventura CA, Sapag J, Brands B, et al. International research capacity building program for health related professionals to study the drug phenomenon in Latin America and the Caribbean. Texto Contexto Enferm [Internet]. 2015 [cited 2015 Nov 28];24(n.spe):17-25. Available from: http://www.scielo.br/pdf/tce/v24nspe/0104-0707-tce-24-spe-00017.pdf

4. Arora A, Kannan S, Gowri S, Choudhary S, Sudarasanan S, Khosla PP. Substance abuse amongst the medical graduate students in a developing country. Indian J Med Res. 2016;143(1):101-3.

5. Nóbrega MPSS, Simich L, Strike C, Brands B, Giesbrecht N, Khenti A. Policonsumo simultâneo de drogas entre estudantes de graduação da área de ciências da saúde de uma universidade: implicações de gênero, sociais e legais,, Santo André - Brasil. Texto Contexto Enferm [Internet]. 2012 [citado 2015 nov. 28];21(n.esp):25-33. Disponível em: http://www.scielo.br/pdf/tce/v21nspe/v21nspea03.pdf

6. Zeferino MT, Hamilton H, Brands B, Wright MGM, Cumsille F, Khenti A. Drug consuption among university students: family, spirituality and entertainment moderating influence of pairs. Texto Context Enferm [Internet]. 2015 [cited 2015 Nov 20]; 24(n.spe):125-135. Available from: http://www.scielo.br/pdf/tce/v24nspe/en_0104-0707-tce-24-spe-00125.pdf

7. Arria AM, Caldeira KM, Bugbee BA, Vincent K B, O'Grady KE. The academic consequences of marijuana use during college. Psychol Addict Behav. 2015; 29(3):564-75

8. Arria AM, Caldeira KM, Allen HK, Vincent KB, Bugbee BA, O'Grady KE. Drinking like an adult? Trajectories of alcohol use patterns before and after college graduation. Alcohol Clin Exp Res. 2016;40(3):583-90. 
9. McBride NM, Barrett B, Moore KA, Schonfeld L. The role of positive alcohol expectancies in underage binge drinking among college students. J Am Coll Health. 2014;62(6):370-9.

10. Ryle R. Questioning gender: a sociological exploration. Thousand Oaks: Sage; 2014.

11. Geertz G. A interpretação das culturas. Rio de Janeiro: LTC; 2014.

12. Connell RW, Messerschmidt JW. Masculinidade hegemônica: repensando o conceito. Rev Estud Fem [Internet]. 2013 [citado 2015 nov. 14];21(1):241-82. Disponível em: http://www.scielo.br/pdf/ref/v21n1/14.pdf

13. Brasil. Ministério da Saúde; Secretaria de Atenção à Saúde, Departamento de Ações Programáticas e Estratégicas. Política Nacional de Atenção Integral à Saúde do Homem: princípios e diretrizes [Internet]. Brasília; 2008 [citado 2015 set. 25]. Disponível em: http://bvsms. saude.gov.br/bvs/publicacoes/politica_nacional_atencao_homem.pdf

14. Brasil. Presidência da República; Secretaria Nacional de Políticas sobre Drogas. Legislação e Políticas Públicas sobre Drogas no Brasil [Internet]. Brasília; 2010 [citado 2015 jan. 20]. Disponível em: http://obid.senad.gov.br/obid/biblioteca/publicacoes/legislacao-e-politicaspublicas-sobre-drogas-no-brasil.pdf

15. Brasil. Ministério da Saúde; Conselho Nacional de Saúde. Resolução n. 466, de 12 de dezembro de 2012. Dispõe sobre as diretrizes e normas regulamentadoras de pesquisas envolvendo seres humanos [Internet]. Brasília; 2012 [citado 2013 mar. 20]. Disponível em: http:// conselho.saude.gov.br/resolucoes/2012/Reso466.pdf

16. Hirsch CD, Barlem ELD, Almeida LK, Tomaschewski-Barlem JG, Figueira AB, Lunardi VL. Coping strategies of nursing students for dealing with university stress. Rev Bras Enferm [Internet]. 2015 [cited 2015 Oct. 20];68(5):783-90. Available from: http://www.scielo.br/pdf/reben/ v68n5/en_0034-7167-reben-68-05-0783.pdf

17. Moraes M. Gênero e usos de drogas: por que é importante articular esses temas? In: Moraes M, Castro R, Petuco D, organizadores. Gênero e drogas: contribuições para uma atenção integral à saúde [Internet]. Recife: Instituto PAPAl; 2011 [citado 2015 set. 17]. Disponível em: http://psicologiasocial.uab.es/fic/es/webfm_send/523

18. Formigoni MLOS, coordenadora. SUPERA: Sistema para detecção do uso abusivo e dependência de substâncias psicoativas: encaminhamento, intervenção breve, reinserção social e acompanhamento [Internet]. Brasília; 2014 [citado 2015 mar.18]. Disponível em: http://www.supera.senad.gov.br/

19. Raup LM, Adorno RCF. Jovens em situação de rua e usos de crack: um estudo etnográfico em duas cidades. Rev Bras Adolesc Conflitual [Internet]. 2011 [citado 2015 nov. 10];4:52-67. Disponível em: http://portal.cnm.org.br/sites/9700/9797/docArtigos/jovensecrack.pdf

20. Bauman Z. Tempos líquidos. Rio de Janeiro: Zahar; 2007.

21. Diehl A, Pillon SC, Jordán MJ. Sexualidad y drogadicción. In: Rodrigues Junior OM, organizador. Cuestiones básicas para la sexologia latinoamericana. São Paulo: Instituto Paulista de Sexualidade; 2014. p. 261-86.

22. Bottorff JL, Haines-Saah R, Kelly MT, Oliffe JL, Torchalla I, Poole N, et al. Gender, smoking and tobacco reduction and cessation: a scoping review. Int J Equity Health. 2014;13:114.

Financial support: Conselho Nacional de Desenvolvimento Científico e Tecnológico (CNPq), through the Public Call of the Casadinho/Procad Program of the Ministry of Science and Technology and Innovation $(\mathrm{MCTI})$, through the Coordenação de Aperfeiçoamento de Pessoal de Nível Superior (CAPES). 